\title{
A Research on Future Aspirations of Adolescents
}

\author{
C. Manoharan, R.Vettriselvan, R.Divyaranjani
}

\begin{abstract}
Education is a process of preparation for future life (John Dewy). This study tries to find out the future aspiration for adolescents in the study area. Aspiration is an individual inner cry to reach the high line in life. It is an attitude of burning fire flame within us that will help to climbs up. As such, factors that influence of high aspirations become important to identify.
\end{abstract}

Rundown phrases-adolescents, aspirations female

\section{I.INTRODUCTION}

Future Aspirations among Adolescents play an important role in their Educational and Perceptual attainment in work life. Aspirations on their hopes and expectations about what they will achieve in the future play an important role in deferring their future outcomes (8). Thus, the aim of this study is to learn about adolescents future aspirations and to enlighten the individual with factors influence them.

\section{NEED FOR THE STUDY}

The age of Adolescence is the time when individuals are more concerned about their future than any of other developmental phases. For Adolescents future Aspirations can be conceptualized as the educational and vocational dreams of their future work lives. In this context the investigator wants to measure the future Aspiration of adolescents, because many studies have not been carried out in this area in our State.

\section{STATEMENT OF THE PROBLEM}

During the age Adolescence, the body and mind go through many complex changes. At the same time lot of distress among Adolescents. They are very much disturbed and difficult to manage themselves in general and particular to think about their future goal in life. In this context "A study on Future Aspirations of Adolescents" is very essential to streamline their work life.

\section{OBJECTIVES OF THE STUDY}

1. To find out the level of future Aspirations of Adolescents

2. To find out the significant difference between the male and female adolescent Students in their future Aspirations
3. To find out the significant difference between the XI and XII standard adolescent students in their future aspirations

4. To find out the significant difference between the adolescent students residing in urban and rural areas in their future aspirations

\section{HYPOTHESES OF THE STUDY}

1. The level of future aspirations of the adolescent is high

2. There is no significant difference between the male and female adolescents students in their future aspirations.

3. There is no significant difference between the XI and XII standard adolescent students in their future aspirations.

4. There is no significant difference between the adolescent students residing in urban and rural areas in their future aspirations.

\section{RESEARCH DESIGN}

The present study is an analytical in nature to analyze the aspiration of adolescents by employed the normative surrey method to collect the responses from the selected adolescents in the study area.

\section{SAMPLE AND POPULATION}

The sample consisted of one thousand (1000) Adolescents from in and around Chennai city.

\section{TOOLS USED}

The future aspiration scale (FAS) was developed and standardized by the investigator. It contains 62 positive and negative items with six dimensions.

\section{STATISTICAL ANALYSIS \& RESULTS}

For analyzing data statistical techniques like mean, standard Deviation, ' $t$ ' tests were applied.

Testing of hypothesis - I

The level of future aspirations of adolescents is high.

Revised Manuscript Received on July 18, 2019.

Dr. C. Manoharan el, Professor, AMET Business School, AMET (Deemed to be University), Chennai, Tamil, India.

Mrs.R.Vettriselvan, Assistant Proffessor, AMET Business School, AMET (Deemed to be University), Chennai, Tamil, India

Dr.R.Divyaranjani, Assistant Proffessor, AMET Business School, AMET (Deemed to be University), Chennai, Tamil, India. 
Table 1

Level of Future Aspirations of Adolescents

\begin{tabular}{|c|l|l|l|l|}
\multicolumn{2}{|l}{ It } & \multicolumn{2}{c}{ inferred } & \multicolumn{2}{c|}{ from } \\
\hline Variable & $\begin{array}{l}\text { No. of } \\
\text { samples }\end{array}$ & Level & Freq. & $\%$ \\
\hline \multirow{2}{*}{$\begin{array}{c}\text { Future } \\
\text { Aspirations }\end{array}$} & 10 & Low & 139 & 13.76 \\
\cline { 3 - 5 } & & Moderate & 717 & 71.98 \\
\cline { 3 - 5 } & & High & 144 & 14.26 \\
\hline
\end{tabular}

above

table that $71.98 \%$ of adolescent students have a moderate level in their future aspiration.

\section{HYPOTHESIS - II}

There is no significant difference between Male and female adolescent students in their future aspirations.

Table 2

Difference in the Future Aspiration of Adolescents Regarding Gender

\begin{tabular}{|c|c|c|c|c|c|c|}
\hline $\begin{array}{l}\text { Variabl } \\
\mathrm{e}\end{array}$ & $\begin{array}{l}\text { Gen } \\
\text { der }\end{array}$ & $\mathrm{N}$ & $\begin{array}{l}\text { Mea } \\
\text { n }\end{array}$ & SD & $\begin{array}{l}\text { 't' } \\
\text { Valu } \\
\text { e. }\end{array}$ & $\begin{array}{l}\text { Level } \\
\text { of } \\
\text { Signi. }\end{array}$ \\
\hline \multirow{2}{*}{$\begin{array}{l}\text { Future } \\
\text { Aspirati } \\
\text { on }\end{array}$} & $\begin{array}{l}\mathrm{Mal} \\
\mathrm{e}\end{array}$ & $\begin{array}{l}42 \\
2\end{array}$ & $\begin{array}{l}218 . \\
87\end{array}$ & 16.14 & \multirow{2}{*}{4.46} & \multirow{2}{*}{$\mathrm{S}$} \\
\hline & $\begin{array}{l}\text { Fem } \\
\text { ale }\end{array}$ & $\begin{array}{l}57 \\
8\end{array}$ & $\begin{array}{l}223 . \\
33\end{array}$ & 14.94 & & \\
\hline
\end{tabular}

(Table value for $998 \mathrm{df}$ at $5 \%$ level $=1.96$ )

From the above table, it is found that table value for 998 degrees of freedom at 5\% level of significance. Hence, there is a significant difference between the male and female adolescent students in their future aspirations.

\section{HYPOTHESIS - III}

There is no significant difference between XI and XII standard adolescent student in their future aspirations.

Table 3

Difference in the Future Aspiration of Adolescents Regarding their Class

\begin{tabular}{|l|l|l|l|l|l|l|}
\hline Variable & Gender & $\mathrm{N}$ & Mean & $\mathrm{SD}$ & $\begin{array}{l}\text { 't' } \\
\text { Value. }\end{array}$ & $\begin{array}{l}\text { Level of } \\
\text { significance }\end{array}$ \\
\hline $\begin{array}{c}\text { Future } \\
\text { Aspiration }\end{array}$ & $\mathrm{XI}$ & 721 & 221.21 & 15.02 & \multirow{2}{*}{2.21} & $\mathrm{~S}$ \\
\cline { 2 - 5 } & $\mathrm{XII}$ & 279 & 223.64 & 16.96 & & \\
\hline
\end{tabular}

(Table value for $998 \mathrm{df}$ at $5 \%$ level $=1.96$ ).

From the above table, it is found that the calculated ' $t$ ' value is greater than the table value for 998 degrees of freedom at $5 \%$ level of significance. Hence there is a significant difference between the X1 and XII standard adolescent students in their future aspirations.

\section{HYPOTHESIS-IV}

There is no significant difference between the adolescent students residing in urban and rural areas in their future aspirations.

Table 4

Difference in the Future Aspirations of Adolescent Students Regarding Locality

\begin{tabular}{|l|l|l|l|l|l|l|}
\hline $\begin{array}{l}\text { Variabl } \\
\text { e }\end{array}$ & $\begin{array}{l}\text { Locali } \\
\text { ty }\end{array}$ & $\mathrm{N}$ & Mean & $\mathrm{SD}$ & $\begin{array}{l}\text { 't' } \\
\text { Valu } \\
\text { e. }\end{array}$ & $\begin{array}{l}\text { Level of } \\
\text { significan } \\
\text { ce }\end{array}$ \\
\hline $\begin{array}{c}\text { Future } \\
\text { Aspirati } \\
\text { on }\end{array}$ & Urban & $\begin{array}{l}37 \\
6\end{array}$ & $\begin{array}{l}223.4 \\
1\end{array}$ & $\begin{array}{l}15.4 \\
7\end{array}$ & \multirow{2}{*}{2.18} & \\
\cline { 2 - 7 } & Rural & $\begin{array}{l}62 \\
4\end{array}$ & $\begin{array}{l}221.2 \\
1\end{array}$ & $\begin{array}{l}15.6 \\
8\end{array}$ & & \\
\hline
\end{tabular}

(Table value for $998 \mathrm{df}$ at $5 \%$ level $=1.96$ ).

From the above table it is found that the calculated ' $t$ ' value is greater than the table value for 998 degrees of freedom at $5 \%$ level of significance. Hence, there is a significant difference between the adolescent students residing from urban areas in their future aspirations.

\section{CONCLUSION}

Aspirations take much importance during the period of adolescent, as youth faced with multiple personal and developmental transitions begin to plan for their future and develop long-term life goals. Research strongly points to the importance of adolescent's future aspirations to their future and educational attainment. As such given the importance of the school environment and formative school setting plays a vital role. The importance of future aspirations attainment points to the need to better understand the supporting and encouraging the development of high aspirations to be attained.

\section{REFERENCES}

1. Hendry Garret 2007 statistics in psychology and education, New Delhi, Paragon International Publications.

2. Angal, M., S.K. 2009 educational Psychology New Delhi. Tandon publication. Ludhiana.

3. George Morrissey, creating your future personal strategic planning for professionals

4. http:Psycnet.apa.org/journals

5. http:www.eric ed.gov/

6. Lakshmi, K., \& Ramachandran, S. (2017). A study of physical activity in children and adolescents. Research Journal of Pharmacy and Technology, 10(10), 36053606.

7. Satyanarayana, N. V., \& Madhavan, B. (2016) Participant perceptions of the influence of spiritual and human values education on their behaviour, character and leadership potential- A qualitative research study. Purushartha, 9(1), 43-51. 
8. Vettriselvan, R., Antony Jesu Rajan, F. S. A., \& Arunkumar, N. (2018). Child labour in unorganized mechanical engineering industries of Tamil Nadu: A situation analysis. International Journal of Mechanical Engineering and Technology, 9(10), 809-819.

9. Vettriselvan, R., \& Ruben Anto, M. (2018). Pathetic health status and working condition of zambian women. Indian Journal of Public Health Research and Development, 9(9), 259-264.

\section{WEBSITES}

1. https://www.srichinmoylibrary.com/ip-7

2. https://files.eric.ed.gov/fulltext/ED545803.pdf 